\title{
Assessment of the Potential of Biomass Gasification for Electricity Generation in Bangladesh
}

\author{
Barun Kumar Das and S. M. Najmul Hoque \\ Department of Mechanical Engineering, Rajshahi University of Engineering and Technology, Rajshahi 6204, Bangladesh \\ Correspondence should be addressed to Barun Kumar Das; barunruet@gmail.com
}

Received 3 January 2014; Accepted 13 May 2014; Published 12 June 2014

Academic Editor: Abdurrahman Saydut

Copyright ( 2014 B. K. Das and S. M. N. Hoque. This is an open access article distributed under the Creative Commons Attribution License, which permits unrestricted use, distribution, and reproduction in any medium, provided the original work is properly cited.

\begin{abstract}
Bangladesh is an agriculture based country where more than 65 percent of the people live in rural areas and over $70 \%$ of total primary energy consumption is covered by biomass, mainly agricultural waste and wood. Only about $6 \%$ of the entire population has access to natural gas, primarily in urban areas. Electricity production in Bangladesh largely depends on fossil fuel whose reserve is now under threat and the government is now focusing on the alternating sources to harness electricity to meet the continuous increasing demand. To reduce the dependency on fossil fuels, biomass to electricity could play a vital role in this regard. This paper explores the biomass based power generation potential of Bangladesh through gasification technology-an efficient thermochemical process for distributed power generation. It has been estimated that the total power generation from the agricultural residue is about $1178 \mathrm{MWe}$. Among them, the generation potential from rice husk, and bagasses is $1010 \mathrm{MWe}$, and $50 \mathrm{MWe}$, respectively. On the other hand, wheat straw, jute stalks, maize residues, lentil straw, and coconut shell are also the promising biomass resources for power generation which counted around $118 \mathrm{MWe}$. The forest residue and municipal solid waste could also contribute to the total power generation 250 MWe and 100 MWe, respectively.
\end{abstract}

\section{Introduction}

1.1. Energy Status in Bangladesh. Bangladesh is one of the world's most densely (1142.29/ $\mathrm{km}^{2}$ in 2010) populated nations with an area of $147,570 \mathrm{~km}^{2}$ and a population of about 150 million [1]. Two-thirds of the country's total population lives in rural areas, meeting most of their energy needs (domestic, commercial, and industrial) from traditional biomass fuels [1] and about $51 \%$ of its populations have no access to power [2]. Bangladesh's per capita energy consumption is very low, the lowest within the Indian subcontinent. The 2010 energy consumption value stands at about $209 \mathrm{kgOE}$ which is quite low compared to $566 \mathrm{kgOE}$ for India, $487 \mathrm{kgOE}$ for Pakistan, $478 \mathrm{kgOE}$ for Sri Lanka, and $341 \mathrm{kgOE}$ for Nepal and far below the world average of $1680 \mathrm{kgOE}$ [1]. The installed capacity in Bangladesh increased by roughly 3,415 MW between 2009 and 2012 and is now about 8,535 MW [3]. According to reports, Bangladesh at present generates $5000 \mathrm{MW}$ power. Peak hour demand is of 6,000 MW every day and increases on hot summer days. Bangladesh's electricity supply strongly relies on natural gas. More than $67.21 \%$ of the power plants are fired by the gas. Hydropower is responsible only for $2.58 \%$ of the total electricity supply. HFO based power plants share around $22.34 \%$ of total electricity. The acute gas shortage causes a loss in production of around 600 MW [3]. Due to the shortage of fossil fuel, government has focused on the renewable energy technology mainly on solar energy and biomass.

In Bangladesh, agricultural residues vastly meet the household energy demands in rural and semiurban areas. This is practiced mainly because of the fact that around 65 percent of our economic activities are based on agriculture. The rain fed ecosystem of Bangladesh produces huge amounts of biomass resources, for example, agriculture residues (crop/tree residue, rice husk, and jute stick), animal waste (cow dung and human excreta), wood/tree leaves, municipal waste, vegetation, sugarcane bagasse, water hyacinth, poultry droppings, garbage, and so forth. Due to the lack of electricity supply in rural areas, the rural population depends mainly on biomass as a source of energy. Only about $6 \%$ of the entire population has access to natural gas, primarily in urban areas. Biomass fuels, such as wood, cow dung, and agricultural 
TABLE 1: Source of cooking fuels (in \%).

\begin{tabular}{lccc}
\hline Fuel type & 2011 & 2004 & 1991 \\
\hline Wood & 34.80 & 31.76 & 44.27 \\
Kerosene & 1.00 & 1.79 & 0.57 \\
Gas/LPG & 12.60 & 9.09 & 2.36 \\
Electricity & 0.40 & 0.76 & 0.88 \\
Straw/leaf/dried & 51.20 & 55.91 & - \\
cow dung & 0.10 & - & - \\
Biogas & & & \\
\hline
\end{tabular}

TABLE 2: Source of lights (in \%).

\begin{tabular}{lccc}
\hline Source & 2011 & 2004 & 1991 \\
\hline Grid electricity & 56.60 & 39.77 & 14.37 \\
Solar energy & 3.30 & - & - \\
Kerosene & 39.50 & 59.93 & 84.73 \\
Biogas & 0.10 & - & - \\
Others & 0.50 & 0.31 & 0.89 \\
\hline
\end{tabular}

residues, are collected mainly from the local environment and have become a traded commodity as cooking fuel. Most Bangladeshi households in rural areas (99\%) as well as urban areas (66\%) use biomass such as wood, cow dung, jute sticks, or other agricultural wastes for cooking and Table 1 presents the different sources of cooking fuels in Bangladesh. Table 2 shows the different sources of lighting for both the urban and rural areas in the country [4].

1.2. Renewable Energy in Bangladesh. Power generation in Bangladesh largely depends on natural gas considering its apparent huge availability. Maximum share of generated power comes from natural gas and the rest is from liquid fuel, coal, and hydropower. The present share of renewable energy is only $0.5 \%$ [5]. However, in recent years, it is evident that actual scenario is different and adequate supply of natural gas has been at stake due to depleting existing gas reserves and nonexploration of new gas reserves. The uncertainty has been constraining development of further gas based power generation expansion program. Considering this situation, the government has diversified the fuel mix and under the new generation expansion plan, substantial proportion is from liquid and is coal based. In that case, the above scenario will be drastically changed. Under the changed perspective, renewable energy would have a significant contribution, given the global climate change scenario and carbon trading prospect. Bangladesh Power Development Board (BPDB), Rural Electrification Board (REB), Local Government Agency like Local Government Engineering Directorate (LGED), and a significant number of private sector agencies including NGOs are involved in renewable energy development. Noted public universities, for example, Bangladesh University of Engineering and Technology (BUET), Rajshahi University of Engineering and Technology (RUET), Khulna University of Engineering and Technology (KUET), and their affiliated Institutes, are involved in research and development of renewable energy applications.

The biggest renewable energy program in Bangladesh is solar home system (SHS). In Bangladesh, SHS project has been implemented under Infrastructure Development Company Limited (IDCOL) and so far installed 900,000 units and still increasing due to an integrated program undertaken by the government through its financial institution, IDCOL. IDCOL's program is considered as a successful model for installation of SHSs in the world. Till now, national capacity of renewable energy based power is approximately $50 \mathrm{MWe}$ [5]. Of them, solar home system alone produces $45 \mathrm{MWe}$, wind energy produces $2 \mathrm{MWe}$, and biomass share is not more than $1 \mathrm{MWe}$.

\section{Biomass Resources in Bangladesh}

2.1. Agricultural Residues. Total area of Bangladesh is about $147,570 \mathrm{~km}^{2}$, where the total agricultural land is about $90500 \mathrm{~km}^{2}$ which is $62.8 \%$ of the total area. Total arable land is $79700 \mathrm{~km}^{2}$ which is $55.3 \%$ of the total area. Approximately $52.54 \%$ of the country's land is used for agricultural practices and $17.50 \%$ for forest [10]. Crop residues represent the nonedible plant parts which are left in the field after harvest and/or remain as byproducts after crop processing, for example, extraction or milling [11]. These residues contribute significantly to the biomass sector of Bangladesh and can potentially be used as energy source for rural electrification. Being an energy source, crop residues are used for several other purposes such as fodder and raw manufacturing material. Paddy straw, rice husks, wheat straw, coconut husk and shell, mastered oil tree, beans, vegetables trees, jute, sugar cane bagasse, and so forth are the major agricultural residues.

Table 3 shows the total residue production in the year 2011 in Bangladesh. With the total agrocrops production of 59.2 million tons [12] and considering the amount of fractions of different types of crops, the total contribution of biomass residue potential is of about 41.66 million tons of straws and husks. The quantities of residues have been estimated by applying a residual factor from several studies for different agricultural crops [13-19]. Straws typically produce around $50 \%$ of the total crops production, whereas rice husk produces $20 \%$ of paddy production, and bagasse produced $36 \%$ of the total sugarcane production.

2.1.1. Characteristics of Agricultural Residue. The energy content or caloric value of the husks varies somewhat with the crops variety, the amount of bran mixed with the husks, and the moisture content of the husks (usually 8 to $10 \%)$. According to the report, the energy in $3 \mathrm{~kg}$ of husk approximately equals that in $1 \mathrm{~kg}$ of fuel oil or $1.5 \mathrm{~kg}$ of coal [20]. Somewhat higher fuel values have been indicated in tests of husks from small mills in developing countries; the inclusion of some bran with the husks tends to increase the percentage of carbon and dilute the ash in the mixture. The high ash contents and the characteristics of the ash impose several severe requirements on the design of the combustion or the gasification systems for the use of rice husk. The higher 
TABLE 3: Total residue production with percentage of fractions of some selected agricultural crops.

\begin{tabular}{|c|c|c|c|c|}
\hline Crops & $\begin{array}{l}\text { Production in } 2011 \\
\text { (million tons) }\end{array}$ & Fractions & Amount of fractions & $\begin{array}{l}\text { Crop residue } \\
\text { (million tons) }\end{array}$ \\
\hline \multirow{2}{*}{ Rice } & \multirow{2}{*}{50.63} & Straw & 50.00 & 25.31 \\
\hline & & Husk & 20.00 & 10.13 \\
\hline \multirow{2}{*}{ Maize } & \multirow{2}{*}{1.02} & Stalks & 200.00 & 2.04 \\
\hline & & Cobs & 30.00 & 0.31 \\
\hline Wheat & 0.97 & Straw & 65.00 & 0.63 \\
\hline \multirow{2}{*}{ Jute } & \multirow{2}{*}{1.52} & Stalk & 58.84 & 0.90 \\
\hline & & Leaves & 13.91 & 0.21 \\
\hline Sugarcane (trimmed) & 4.67 & Bagasse & 36.00 & 1.68 \\
\hline Mustard & 0.23 & Straw & 75.00 & 0.17 \\
\hline \multirow{2}{*}{ Coconut } & \multirow{2}{*}{0.08} & Husk & 31.00 & 0.024 \\
\hline & & Shell & 24.40 & 0.019 \\
\hline \multirow[t]{2}{*}{ Lentil } & 0.081 & Straw & 72.46 & 0.058 \\
\hline & \multicolumn{3}{|c|}{ Total residue production in 2011 (million tons) } & 41.66 \\
\hline
\end{tabular}

TABLE 4: Proximate and ultimate analysis of some selected agricultural residues $[8,9]$.

\begin{tabular}{lccccccccc}
\hline Crops residue & Fixed carbon (\%) & Volatile matter (\%) & Ash (\%) & C (\%) & H (\%) & O (\%) & N (\%) & S (\%) & HHV MJ/kg \\
\hline Rice straw & 14.01 & 61.2 & 20.49 & 39.99 & 3.94 & 30.26 & 0.79 & 0.2 & \\
Rice husk & 16.22 & 63.52 & 20.26 & 38.83 & 4.75 & 35.47 & 0.52 & 0.05 & $15-17$ \\
Wheat straw & 19.80 & 71.30 & 8.90 & 43.20 & 5.00 & 39.40 & 0.61 & 0.11 & \\
Maize stalks & 16.03 & 70.31 & 5.25 & 44.20 & 5.80 & 43.5 & 1.30 & 0.01 & 14.66 \\
Maize cobs & 16.67 & 64.32 & 19.00 & 39.60 & 5.17 & 34.06 & 1.78 & 0.38 & 15.65 \\
Jute stalk & 21.00 & 76.05 & 0.62 & 49.79 & 6.02 & 41.37 & 0.19 & 0.05 & 19.70 \\
Sugarcane bagasse & 14.95 & 73.78 & 11.27 & 44.80 & 5.35 & 39.55 & 0.38 & 0.01 & 18.10 \\
Mustard straw & 17.66 & 68.36 & 6.34 & 46.48 & 5.08 & 33.36 & 0.74 & 0.36 & \\
Coconut shell & 22.01 & 71.84 & 0.47 & 49.41 & 6.20 & 37.29 & 0.28 & 0.75 & 20.58 \\
Lentil straw & 24.00 & 72.00 & 4.00 & 46.60 & 5.60 & 42.80 & 0.70 & 0.01 & 15.20 \\
\hline
\end{tabular}

heating value $(\mathrm{HHV})$ indicates the energy content of a given biomass. Table 4 presents the proximate and ultimate analysis of some selected agricultural residues.

The typical HHV of agricultural residue ranges between $15 \mathrm{MJ} / \mathrm{kg}$ and $17 \mathrm{MJ} / \mathrm{kg}[8,9]$. Proximate analysis is the analysis of waste to determine moisture, volatile matter, ash, and fixed carbon. The agricultural residues contain high portions of volatile solids as 61 to $76 \%$, ash residue as 0.47 to $20.49 \%$, and fixed carbon as 14 to $24 \%$. Ultimate analysis is the percent of carbon, hydrogen, oxygen, nitrogen, sulphur, and ash. Analysis shows that carbon content is 38 to $50 \%$, hydrogen is around $6 \%$, oxygen is 30 to $43 \%$, and nitrogen is around $2 \%$ and traces amount of sulphur.

2.2. Forest Residue. According to Bangladesh Bureau of Statistics and Department of Forest, a total of 2.52 million hectares area which is nearly 17.4 percent of the land mass is forests, of which 1.52 million hectares are under direct control of the department. Homestead Trees supplies a significant amount of fuelwood which mainly consists of firewood, twigs, and leaves. The trees are supplied as timber to urban and semiurban areas sawmill and to wood processing industries. The data concerning wood residues from different types of timber logs, that is, sawlogs and veneer logs, plywood and split logs, pulpwood and particle board, and production of fuelwood in 2011, were gathered from Food and Agriculture Organization (FAO) FAOSTAT Statistics Database 2011 [20]. Table 5 presents the amount of forests residue produced in Bangladesh.

2.3. Municipal Solid Waste. Municipal solid waste (MSW) is the heterogeneous composition of wastes that are organic and inorganic, rapidly and slowly biodegradable, fresh and putrescible, and hazardous and nonhazardous, generated in various sources in urban areas due to human activities [21]. Due to the rapid urbanization, municipal produces a huge quantity of solid wastes. It has adverse effect of the environment and the public health. Rural population waste generates only $0.15 \mathrm{~kg}$ per capita per day, while the urban population generates 0.4 to $0.5 \mathrm{~kg}$ per capita per day in Bangladesh [22]. The generation rate is very close in each major city [23]. Overall, the per capita generation varies from house to house depending on the economic status, food habit, age and gender of household members, and seasons. MSW is generated from different sources as 75 to $85 \%$ residential, 11 to $22 \%$ commercial, 1 to $1.5 \%$ institutional, and 0.5 to $1.25 \%$ 
TABLE 5: Forests products in Bangladesh.

\begin{tabular}{lc}
\hline Forest products & Production in 2011 \\
\hline Sawlogs and veneer logs & $174000 \mathrm{~m}^{3}$ \\
Plywood & $1000 \mathrm{~m}^{3}$ \\
Sawnwood & $388000 \mathrm{~m}^{3}$ \\
Wood fuel & $27286834 \mathrm{~m}^{3}$ \\
Industrial roundwood & $282000 \mathrm{~m}^{3}$ \\
Pulpwood round and splits & $18000 \mathrm{~m}^{3}$ \\
Particle board & $2200 \mathrm{~m}^{3}$ \\
Hardboard & $5100 \mathrm{~m}^{3}$ \\
Wood charcoal & 326684 tons $^{3}$ \\
Paper and paperboard & 8000 tons \\
Writing and printing paper & 30000 tons \\
Fiber pulp & 18000 tons \\
Newsprint & 20000 tones \\
\hline
\end{tabular}

others. There is an insignificant variation of composition in MSW at six major districts of Bangladesh. Table 6 presents the total waste generation per day based on the population of the six major districts of Bangladesh. The rapidly biodegradable portion is normally very high compared to other portions, essentially due to the use of fresh vegetables and Fruits. The compositions are 68 to $81 \%$ food and vegetables, 7 to $11 \%$ paper and paper products, 3 to $5 \%$ polythene and plastics, and 9 to $16 \%$ others [23].

The major physical characteristics measured in waste are (1) density, (2) size distribution of components, and (3) moisture content. Other characteristics which may be used in making decision about solid waste management are (1) colour, (2) voids, (3) shape of components, (4) optical property, (5) magnetic properties, and (6) electric properties [24]. Proximate analysis is the analysis of waste to determine moisture, volatile matter, ash, and fixed carbon. The wastes contain high portions of volatile solids as 43 to $71 \%$, ash residue as 29 to $57 \%$, high moisture content as 56 to $70 \%$, bulk density as 550 to $1125 \mathrm{~kg} / \mathrm{m}^{3}$, grain size from 2 to $200 \mathrm{~mm}$, and $\mathrm{pH}$ from 7.7 to 8.7. Ultimate analysis is the percent of carbon, hydrogen, oxygen, nitrogen, sulphur, and ash. Analysis shows that carbon content is 43 to $50 \%$, hydrogen is around $6 \%$, oxygen is 36 to $45 \%$, and nitrogen is 0.2 to $3.5 \%$ and traces amount of sulphur [25-27].

\section{Biomass to Energy Conversion Technology}

There are many bioenergy routes which can be used to convert raw biomass feedstock into a final energy product. Several conversion technologies have been developed that are adapted to the different physical nature and chemical composition of the feedstock and to the energy required (heat, power, and transport fuel) [28]. Recent years have therefore seen considerable effort devoted to the search for the best ways to use these potentially valuable sources of energy. Considering the methods for extracting the energy, they can be ordered by the complexity of the process involved as follows:
(1) direct combustion of biomass;

(2) thermochemical processing to upgrade the biofuel: processes in this category include pyrolysis, gasification, and liquefaction;

(3) biological processing: natural processes such as anaerobic digestion and fermentation, encouraged by the provision of suitable conditions, again lead to a useful gaseous or liquid fuel.

3.1. Incineration. Incineration is a common technique and the earliest one for producing heat and power from biomass. For a more energy efficient use of the biomass resource, modern, large-scale heat applications are often combined with electricity production in combined heat and power (CHP) systems. Cocombustion (also called cofiring) in coalbased power plants is the most cost-effective use of biomass for power generation. Dedicated biomass combustion plants are also in successful commercial operation and many are industrial or district heating CHP facilities. Plant efficiency is around $30 \%$ depending on plant size. This technology is used to dispose of large amounts of residues and wastes (e.g., bagasse). Using high-quality wood chips in modern $\mathrm{CHP}$ plants with maximum steam temperature of $540^{\circ} \mathrm{C}$, electrical efficiency can reach $33-34 \%$ (LHV) and up to $40 \%$ if operated in electricity-only mode. Fossil energy consumed for biopower production using forestry and agriculture products can be as low as $2-5 \%$ of the final energy produced. Based on life-cycle assessment, net carbon emissions per unit of electricity are below $10 \%$ of the emissions from fossil fuel-based electricity. Incineration of biomass is a mature technology. During operation of biomass to energy, emission control is very important and its major effluents are flue gas, ash, and wastewater. Dioxins emission from biomass thermal treatment has been a major issue that concerns people. To secure dioxins emission, further treatment for flue gas can be applied with activated carbon injection before dust collection or SCR (catalyst) after dust collection. This recent development of the preventive technologies has made it possible to reduce the amount of dioxins to the level of public acceptance emissions of pollutants and dioxin can be effectively controlled, but in many countries, incinerators face public acceptance issues and are seen as competing with waste recycling [29].

3.2. Biochemical Conversion. In the absence of air, organic matter such as animal manures, organic wastes, and green energy crops (e.g., grass) can be converted by bacteriainduced fermentation into biogas (a $40-75 \%$ methane-rich gas with $\mathrm{CO}_{2}$ and a small amount of hydrogen sulphide and ammonia). Anaerobic digestion is also the basic process for landfill gas production from municipal green waste. It has significant potential, but it is characterised by relatively small plant size. Anaerobic digestion is increasingly used in small-size, rural, and off-grid applications at the domestic and farm-scale. In general, $50 \%$ of such gas can be recovered and used for power and heat generation. After purification and upgrading, biogas can be used in heat plants and stationary engines, fed into the natural gas grid, or used as a transport 
TABLE 6: MSW generation in six major districts of Bangladesh.

\begin{tabular}{|c|c|c|c|c|c|c|}
\hline MSW generation & Dhaka & Chittagong & Khulna & Rajshahi & Barisal & Sylhet \\
\hline Population (millions) $^{4}$ & 11.9 & 7.5 & 2.3 & 2.6 & 2.3 & 3.4 \\
\hline MSW generation (tons/day) & 5770 & 2700 & 796 & 1042 & 748 & 1462 \\
\hline MSW generation rate (kg/capita/day) & 0.485 & 0.360 & 0.346 & 0.401 & 0.325 & 0.430 \\
\hline
\end{tabular}

fuel (compressed natural gas). Large-size plants using MSW, agricultural wastes, and industrial organic wastes (large-scale codigestion) need 8000-9000 tons MSW per year per MW of installed capacity.

3.3. Pyrolysis. Pyrolysis is a thermochemical decomposition of organic material at elevated temperatures without the participation of oxygen. Conventional pyrolysis involves heating the original material in the near absence of air, typically at $300-500^{\circ} \mathrm{C}$, until the volatile matter has been driven off. The residue is then the char more commonly known as charcoal, a fuel which has about twice the energy density of the original and burns at a much higher temperature. With more sophisticated pyrolysis techniques, the volatiles can be collected, and careful choice of the temperature at which the process takes place allows controlling their composition. The liquid products have potential as fuel oil but are contaminated with acids and must be treated before use. Fast pyrolysis of plant material, such as wood and nutshells, at temperatures of $800-900^{\circ} \mathrm{C}$ leaves as little as $10 \%$ of the material as solid char and converts $60 \%$ into a gas rich in hydrogen and carbon monoxide. At present, the preferred technology is fast or flash pyrolysis at high temperatures with very short residence time [30].

3.4. Gasification. During a gasification process, biomass is directly converted to synthesis gas (syngas) in a gasifier under a controlled amount of air. Syngas can be used in internal combustion (IC) engine to produce power or in a cogeneration system to produce heat and electricity. Previously, Kapur et al. calculated the unit cost of electricity of using rice husk gasifier based power generation system and evaluated its financial feasibility with utility supplier and diesel generated electricity [31]. Abe et al. [32] discussed the potential of rural electricity generation via biomass gasification system. The results suggest that even though agricultural residues such as rice husks may contain high energy potential, supplying a biomass gasification system in the long term may require tree farming in order to provide sufficient amount of resources [32]. These researches imply that the feasibility of these largescale projects is greatly dependent on the plant location that affects the resource availability and the incurred logistic costs of the selected biomass feedstock. On an industrial scale, biomass gasification and power generation systems have been well-established.

Biomass gasification is a multistep process. The chemistry of biomass gasification is similar to that of coal gasification in the sense that thermal decomposition of both solids occurs to yield a mixture of essentially the same gases [33]. However, biomass gasification occurs under much less severe operating conditions than for coal feedstock because its main constituents, the high-oxygen cellulosics and hemicellulosics, have higher reactivity than the oxygen deficient, carbonaceous materials in coal [34]. Biomass gasification is a thermochemical conversion process in which a solid biomass fuel, for example, wood and rice husk, is converted into a combustible gas. In practice, the gasification of the biomass particle occurs through a first particle drying step, followed by a pyrolytic step which leads to devolatilization and shrinking of the original particle. With the last step being char gasification, the pyrolysis step occurs gradually from the surface to the centre of a biomass particle. In a biomass gasifier, biomass is burned in a limited amount of air. The amount of air supplied is less than the amount of air required for complete burning. This converts the biomass (which consists of carbon, hydrogen, oxygen, etc.) into an inflammable mixture of gases known as producer gas/wood gas. The producer gas consists of carbon monoxide $(\mathrm{CO})$, hydrogen $\left(\mathrm{H}_{2}\right)$, and methane $\left(\mathrm{CH}_{4}\right)$, along with carbon dioxide $\left(\mathrm{CO}_{2}\right)$ and nitrogen $\left(\mathrm{N}_{2}\right)$. The nitrogen is not combustible; however, it does occupy volume and dilutes the syngas as it enters and burns in an engine. A generalized reaction describing biomass gasification is in Figure 1.

Classification of biomass gasifiers based on the density factor (ratio of dense biomass phase to total reactor volume) is a simple and effective method of classification. In this way the gasifiers can be classified into (a) dense phase gasifiers and (b) lean phase gasifiers. In lean phase gasifiers, for example, fluidized bed, the biomass occupies very little reactor volume, that is, 0.05-0.2. Most of the gasifiers employed for decentralized applications in developing countries are dense phase reactors, mostly fixed bed reactors; they have typical density factor of $0.3-0.08$ [35].

3.4.1. Updraft Gasifiers. In this type of reactor, air is taken in at the bottom, and the gas leaves at the top. The biomass moves counter to the gas flow and passes successively through drying, pyrolization, reduction, and hearth zones. Gases follow a natural upward movement as the increasing temperature reduces their density. Updraft gasifier can be designed to work under a natural or forced draft. With this configuration, the air or oxidizing agent entering gets in contact with the chars creating the combustion zone. The gases coming out of the combustion zone have to pass through the layer of chars above them created by the heat of the combustion zone. Here, $\mathrm{CO}_{2}$ and $\mathrm{H}_{2} \mathrm{O}$ are reduced into $\mathrm{CO}$ and $\mathrm{H}_{2}$. The reduced gases still contain enough energy to pyrolyze the descending biomass along a range 200 to $500^{\circ} \mathrm{C}$, thus creating the chars that feed the combustion zone. In a reaction chain, pyrolysis gases also have sufficient temperature to dry the wet biomass entering above them. However, during pyrolysis, 


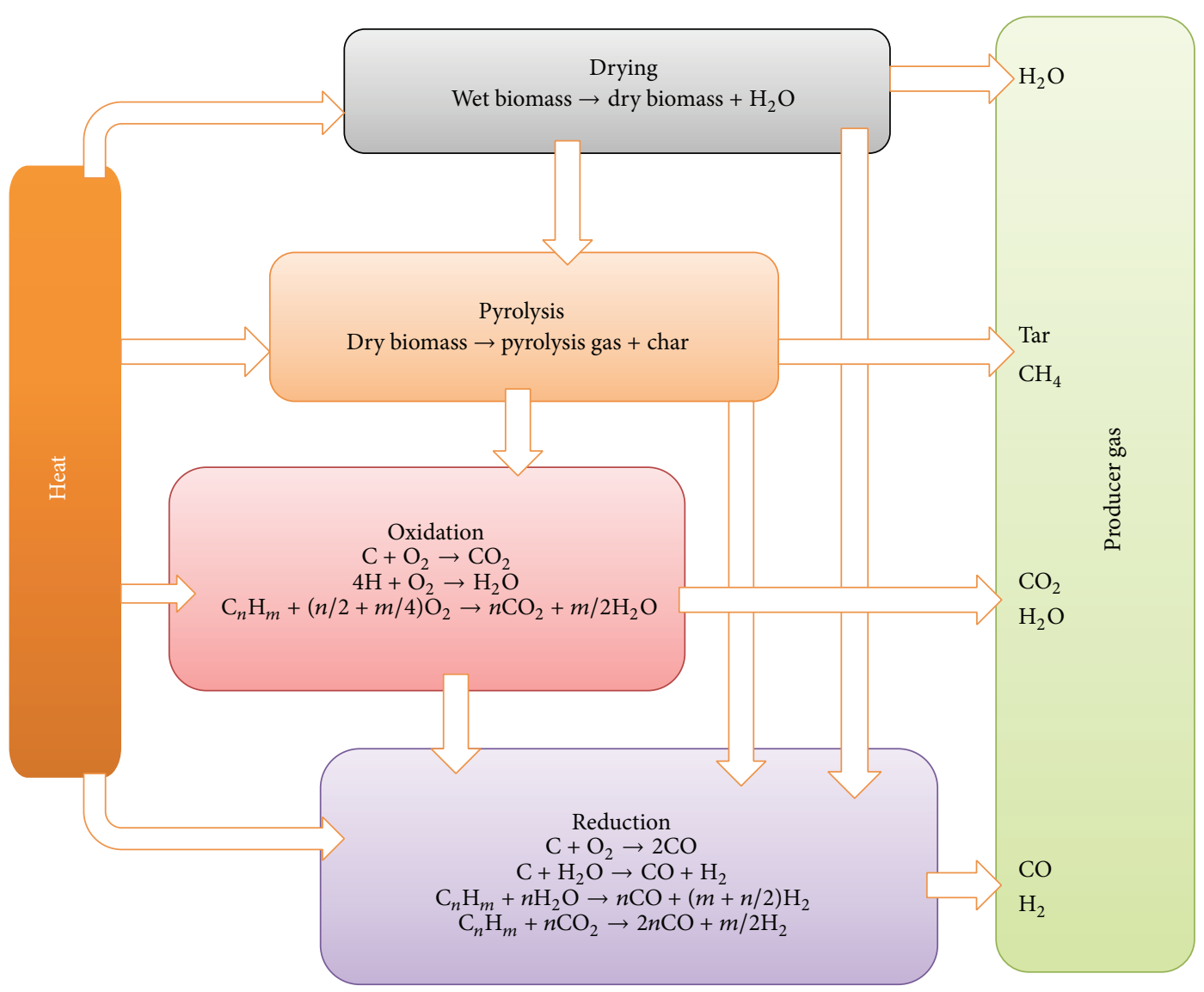

FIGURE 1: The reaction mechanism of biomass gasification process [6].

chemicals, tars, and oils are released and they become part of the producer gases. This drawback restrains the application of the updraft gasifier, because these products released from pyrolysis would be detrimental in a heat engine; however, it could be used for heating applications [36]. Another major drawback in updraft gasifier is due to high temperature at the grate melting ashes, leading to slagging.

3.4.2. Downdraft or Cocurrent Gasifiers. In the downdraft gasifier, air enters at the middle level of the gasifier above the grate, and the resultant mixture of air and gas flows down into the gasifier reactor through the high temperature oxidation zone resulting in thermal cracking of volatiles resulting in a gas which has relatively lower tar content and is better suited for use in engines. This type of gasifier is cheap and easy to make. Such systems have shorter contact times and therefore are more responsive than updraught gasifiers to surge in gas demands that are experienced when fuelling engines $[37,38]$. This gasifier is, however, preferred to updraft gasifier for internal combustion engines because of the low tar content with the syngas.

3.4.3. Fluidized-Bed Gasification. Fluidized-bed gasification was initially developed to overcome operational problems of fixed bed gasification of fuels with high ash content but is suitable for large capacities (more than $10 \mathrm{MW}$ ) in general
[34]. The fuel is fed into a suspended (bubbling fluidized-bed) or circulating fluidized-bed hot sand bed. The bed behaves like a fluid and is characterized by high turbulence. Fuel particles mix quickly with the bed material, resulting in rapid pyrolysis and a relatively large amount of gases. Major problems with fluidized-bed gasification are the resulting high tar content [35], incomplete carbon combustion, and poor response to load changes. Problems with feeding, instability of the reaction bed, and fly-ash sintering in the gas channels can occur with some biofuels [38]. There are two principal types of fluidized-bed gasifiers, namely, bubbling fluidized bed and circulating fluidized bed. Fluidized-bed gasifiers have been the focus of appreciable research and development for large-scale generation.

3.4.4. Biomass Gasification in Bangladesh. A $250 \mathrm{~kW}$ rice husk gasifier based power plant has been installed and commissioned in Kapasia, Bangladesh, in October 2007 (Figure 2). The gasification system comprises $150 \mathrm{~kg} / \mathrm{hr}$ capacity down draft reburn gasifier reactor with gas cleaning and cooling system. At first, rice husk is fed into the gasifier and gas is produced inside the gasifier. The raw producer come out with the reactor temperature at about $450^{\circ} \mathrm{C}$ to $600^{\circ} \mathrm{C}$ with contaminants in form of particulate matter $\left(1000 \mathrm{mg} / \mathrm{Nm}^{3}\right)$ and $\operatorname{tar}\left(150 \mathrm{mg} / \mathrm{Nm}^{3}\right)$. The hot dust laden gas is further processed in the gas cooling and cleaning system in order to 
TABLE 7: Plant technical details [7].

\begin{tabular}{ll}
\hline Parameters & Description \\
\hline Gasifier type & Downdraft $(250 \mathrm{~kW})$ \\
Rated gas flow & $625 \mathrm{Nm}^{3} / \mathrm{hr}$ (up to total $250 \mathrm{~kW}$ capacity) \\
Rated biomass consumption & $\mathrm{Up} \mathrm{to} 300 \mathrm{~kg} / \mathrm{hr}$ (for total $250 \mathrm{~kW}$ capacity) \\
Gasification temperature & $1050^{\circ} \mathrm{C}-1100^{\circ} \mathrm{C}$ \\
Gasification efficiency & $\mathrm{Up}$ to $75 \%$ \\
Temperature of gas at gasifier outlet & 250 to $400^{\circ} \mathrm{C}$ \\
Biomass feeding & Manual \\
Desired operation & Continuous (minimum 300 days $/ \mathrm{yr}$ ) \\
Typical auxiliary power consumption & Up to $11 \mathrm{~kW}$ \\
Typical gas composition & CO-20.62\%, $\mathrm{H}_{2}-10.62 \%, \mathrm{CO}_{2}-13.61 \%, \mathrm{CH}_{4}-\mathrm{Up}_{\mathrm{p}}$ to $4 \%, \mathrm{~N}_{2}-52.62 \%$ \\
Gas purifications unit & Coarse filter, sawdust fine filters, fabric safety filter $(5$ micron particulate size), wet scrubbers \\
Engine & $300 \mathrm{~kW}$ capacity dual fuel generator (producer gas to diesel ratio is $70: 30)$ \\
\hline
\end{tabular}

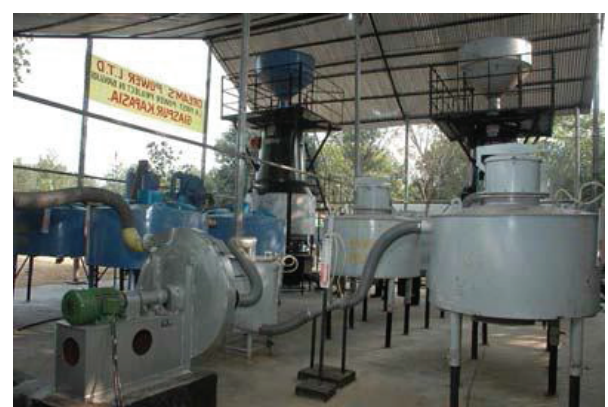

FIgURE 2: Rice husk fired $250 \mathrm{~kW}$ gasifier power plant at Kapasia, Bangladesh [7].

condition the gas to a level that is acceptable for engine operations. Firstly, the hot gas passes through a high efficiency cyclone which separates the dry particulate matter from the raw gas $(\sim 80 \%)$. The next intermediate process of gas cooling and scrubbing is carried in ejector design scrubbers. The wash water for gas scrubbing is used in recycling mode after necessary treatment in the integral effluent treatment plant. The cooled and cleaned gas is further processed in another scrubber such that the resultant gas contains particulate and $\operatorname{tar}(\mathrm{P} \& \mathrm{~T})$ matter less than $1 \mathrm{mg} / \mathrm{Nm}^{3}$. A $300 \mathrm{~kW}$ capacity dual fuel generator is used to generate electricity. In this rice husk based power plant, running the generator certain amount of diesel is required, because the producer gas has relatively lower heating value and needs to be supplemented by diesel to get the necessary power output. That is why the IC engine has been converted into dual fuel mode; that is, it can run both on producer gas and diesel. Here, the producer gas to diesel ratio is $70: 30$. During startup of the plant, main generator is started first on diesel and then changed over to dual fuel mode when the producer gas is available for charging to the engine. Plant technical details are presented in Table 7.

3.4.5. Selection of Biomass Gasification Technologies. The choice of one type of gasifiers over another is dictated by fuel, its final available form, size, moisture content, and ash content. Fixed bed gasifiers are more suitable for smallscale power generation and industrial heating applications [39]. Four types of reactors exist: updraft or countercurrent gasifiers, downdraft or cocurrent gasifiers, cross-draft gasifiers, and fluidized-bed gasifiers. In general, gasification technology is selected on the basis of available fuel quality, capacity range, and gas quality conditions. Downdraft gasifier is suitable for $1 \mathrm{~kW}$ to $1 \mathrm{MW}$ range thermal capacity, whereas updraft is $1.1 \mathrm{MW}$ to $12 \mathrm{MW}$, fluidized-bed gasifier is $1 \mathrm{MW}$ to $50 \mathrm{MW}$, and cross-draft gasifiers are $10 \mathrm{MW}$ to $200 \mathrm{MW}$ range thermal capacity [36].

Downdraft gasifier system can be chosen for Bangladesh's perspective due to its simplicity in construction and cost competitiveness. Downdraft gasifier produces very small amount of tar and with little treatment it can be used directly in the internal combustion engine. Also, the technologies of these systems are quite matured in the world. Based on the above comparative discussions, however, a downdraft gasifier is better than an updraft gasifier system in many aspects. This gasifier has some unique advantages like suitability to small- scale production $(50-150 \mathrm{~kW})$, minimum operating labor required, exhaust type (particularly \% of tar content), and easy as well as less maintenance required.

\section{Power Generation Potential from Biomass}

The producer gas so obtained is a low calorific value gas with typical higher heating value in the range of $5.4-5.7 \mathrm{MJ} / \mathrm{m}^{3}$ [40]. The producer gas can be directly burned in a burner to provide thermal energy or it can be used as a fuel in an engine to provide mechanical power or electricity. The actual biomass syngas composition depends on the gasification process, the gasifying agent, and the feedstock composition [36]. Various gasification technologies have been under investigation for converting biomass into a gaseous fuel. A characteristic of the various gasifiers is the way in which the fuel is brought into contact at the gasification stage.

The combustible producer gas from biomass gasification either can be used in a diesel engine together with a small 
fraction of diesel in dual fuel mode [41-44] or can be used directly in a spark ignition engine (SI) $[45,46]$. Biomass gasification technology has proved to be an efficient way of using biomass at power levels in the range of a few $\mathrm{kW}$ to about 2 MW capacity.

In recent years, biomass gasifiers have been used for electrification of remote villages. The size of such systems can vary from $10 \mathrm{kWe}$ to $500 \mathrm{kWe}$. In India, several of the smaller size (10-20 kWe) biomass gasifier systems have been established under two government of India schemes called Remote Village Electrification (RVE) and Village Energy Security Programme (VESP) [46]. Apart from the government programmes, several NGOs and corporates have also established such systems. There have been a few instances like $500 \mathrm{kWe}$ biomass gasifier based power plant at Gosaba island in Sundarbans (India) where large capacity gasifiers have been used. There are some examples of grid-connected biomass gasifier power plants. These are relatively large sized gasifiers with capacities ranging in hundreds of $\mathrm{kW}$. In India, a typical example is Arashi Hitech Bio Power, an independent power producer (IPP), which has set up a gasifier based power plant linked to the State grid. It is located in Sultanpet village in Coimbatore district of Tamil Nadu, where there is abundance availability of coconut shells. The power plant comprises a biomass processing system, gasification system, programmable logic controller (PLC) based automation and control system, full-fledged water treatment plant, power package, and a power evacuation system. In the first phase, an $800 \mathrm{~kg} / \mathrm{hr}$ gasifier system was integrated with a low speed marine diesel engine in July 2002. The power plant has operated in the dual fuel mode at an average load of $600 \mathrm{kWe}$ for nearly 6000 hours. The average liquid fossil replacement recorded is about $68 \%$, with specific biomass consumption being $0.6-0.7 \mathrm{~kg} / \mathrm{kWh}$. Recently, the dual fuel engine has been replaced with $5 \times 250 \mathrm{kWe}$ producer gas engines [47].

Amongst the bioenergy technologies, the biomass gasification option for meeting the rural electricity needs of domestic, irrigation, and rural small and cottage industrial as well as thermal activities is shown to have a large potential. Gasification is the technology capable of producing fuel gas from conversion of biomass, which can serve the need of energy in various forms. In recent years, biomass gasification technology seems to have given concerns around the world. It is an efficient way to utilize waste biomass and the gas produced from gasification can be used for generating electricity. Gasification produces less harmful exhaust as biomass is very low in sulfur, chlorine, or heavy metals, which are detrimental to the environment. The biggest advantage of gasification is the use of variety of feedstock and products, as the syngas can also be used for chemical industry along with power generation.

Being an agricultural country, Bangladesh has strong potential for power generation from agricultural residues. Bangladesh is among the top five rice producing countries in the world. Rice is the main crop of the country in terms of arable area and production. The production of rice husk and rice straw was 10.12 million tons and 25.31 million tons, respectively, in 2011 [12]. According to the rice mills owners association of Bangladesh, over 100,000 rice mills are scattered all over the country. Most of the mills are geographically concentrated in the four distinct cluster areas and $90 \%$ of them are small in capacity (5-10 MT/day). Other than 4 distinct cluster areas for rice mills in Bangladesh, it will be difficult to keep the continuous supply to the plant [48]. So, it needs to mixed up with locally available biomass so that in can meet the distributed energy/power system at various output levels. Study shows that the downdraft gasifier is suitable for small-scale biomass gasification based power plant $[49,50]$. Consumption of rice husk is $1.86 \mathrm{~kg}$ per $\mathrm{kWh}$ electricity generation for gasification based power plant [51]. Assuming 50\% of the rice husk and straw availability for power generation, the potential of power generation from rice husk and straw is around 1010 MWe.

Bangladesh, having about 15 sugar mills, produces around 1.68 million tons of bagasse in 2011 which is sufficient to produce power. In the north-western region, which is starved for energy, the sugar mills would be a great energy resource. This is also an advantage as all the 15 sugar-producing units were installed in the region. The bagasse has the potential to produce power around $50 \mathrm{MWe}$ which would be able to consume the mills itself and the rest of the power can be supplied to the nearby areas or to the national grid as well. Government of Bangladesh would need to amend energy policy so that the gasification plants can run to their full capacity and can sell the surplus electricity to the grid.

Wheat straw, jute stalks, maize residues, lentil straw, and coconut shell are also the promising biomass resources for power generation as well. Counting all the agricultural residues about 41.26 million tons as stated in Table 3 , it is estimated, assuming 50\% residue for power generation, that the total potential for power generation from biomass is 1178 MWe.

Bangladesh has very limited forest resources. Broadly speaking, Bangladesh's forests can be divided into four types: (1) mangrove forests in the coastal delta, (2) hill forests in the interior, (3) sal (Shorea robusta) forests in smaller areas inland, and (4) social forests. The bioenergy potential from wood residues is not high but it has significant importance to different level of consumers in rural areas. Nevertheless, fuelwood is the major sources of supplying wood energy in the country. Most of the household uses fuelwood for cooking purposes in the rural areas. However, efficient use of forest residues could be a renewable source of energy in any given part of Bangladesh. Forest residue comprises small branches, leaves, corn stove, and so forth. Bangladesh has good potential of harvesting bioenergy from forest residues by setting up biomass gasifier in forest regions to produce power. On the basis of the forests residue available in Bangladesh and assuming that a small fraction ( $~ 30 \%$ availability) of residues is available from the forests, the possible power potential is about 250 MWe.

Main parameters determining the potential of energy recovery from wastes (including MSW) are quantity of waste and physical and chemical characteristics (quality) of the waste. The actual production of energy will depend upon specific treatment process in use, the selection of which is also significantly dependent upon the above two parameters. The important physical parameters requiring consideration 
include constituent's size, density, and moisture content. Smaller size of the constituents helps in faster decomposition of the waste [52]. Considering the quality and moisture contents of the municipal solid waste (MSW) of major cities in Bangladesh, it is estimated that around 100 MWe of electricity can be produced from the municipal solid waste.

\section{Conclusion}

Biomass gasification can offer an attractive alternative renewable energy system especially in rural areas where biomass fuel is readily available. These resources could provide community based small-scale independent power plants. Rice husk and straw can be ranked the top of the available biomass types in Bangladesh and have power generation potential of around $1010 \mathrm{MWe}$. The power plant could be installed near the larger rice mills' "cluster areas" in Dinajpur, Bogra, Naogaon, Chapainawabganj, and Ishwardi with the surplus rice husk. However, establishment of bagasse based power plants in sugar industries will lead to an enormous change in the sugar production and the rest of power will be supplied to national grid and to the local communities. However, other types of biomass such as rind of pulses saw dust should also be considered for gasification. Bangladesh has a significant potential form of power generation from biomass gasification and has estimated around 1500 MWe. Provision of government subsidies need to overcome the barriers for the installation of such gasification power plants. Government can seek funds from different foreign aids. Also carbon trade can be an option. Installation of biomass based power plants in rural areas will lead to an enormous change in the lifestyle of the local communities. Increased lighting would also indirectly help the community by increasing the business hours in the market area, improving health conditions, and encouraging new business developments.

\section{Nomenclature}

\author{
MWe: Megawatt of electricity \\ MW: Megawatt \\ kW: Kilowatt \\ kWe: Kilowatt of electricity \\ kWh: Kilowatt hour \\ kgOE: Kilograms of oil equivalent \\ HFO: Heavy fuel oil \\ NGOs: Nongovernmental organizations \\ MT: Metric tonne.
}

\section{Conflict of Interests}

The authors declare that there is no conflict of interests regarding the publication of this paper.

\section{References}

[1] World Bank, Bangladesh: Bolstering Economic Growth to Reduce Poverty, 2011, http://www.worldbank.org.bd/.

[2] http://www.energybangla.com/.
[3] BPDB: Bangladesh Power Development Board, "Key Statistics," December 2012, http://www.bpdb.gov.bd/bpdb/index.php? option $=$ com_content\&view=article\&id=5\&Itemid $=6$.

[4] Population and Housing Census, 2011, http://203.112.218.66/WebT estApplication/userfiles/Image/BBS/Socio_Economic.pdf.

[5] Renewable Energy Bangladesh, Power Division, Ministry of Power, Energy and Mineral Resources, Government of the People's Republic of Bangladesh, http://www.powerdivision.gov .bd/user/brec/49/89.

[6] Y. S. Sherka, Design and performance evaluation of biomass gasifier stove [M.S. thesis], Institute of Technology Chemical Engineering, Department Environmental Engineering Stream, Addis Ababa University, Addis Ababa, Ethiopia, 2011.

[7] Biomass Technologies-Biomass Gasification in Bangladesh, Infrastructure Development Company Limited, Dhaka, Bangladesh, http://practicalaction.org/media/preview/7167/lng:en.

[8] S. Grover, R. S. Kathuria, and M. Kaur, "Energy values and technologies for non woody biomass: as a clean source of energy," IOSR Journal of Electrical and Electronics Engineering, vol. 1, no. 2, pp. 10-14, 2012.

[9] Biomass Energy Foundation: Proximate/Ultimate Analysis, http://drtlud.com/BEF/proximat.htm.

[10] Bangladesh Bureau of Statistics (BBS), Statistical Yearbook of Bangladesh 2009, Planning Division, Ministry of Planning Government of People's Republic of Bangladesh, 2010.

[11] F. Bernard and A. Prieur, "Biofuel market and carbon modeling to analyse French biofuel policy," Energy Policy, vol. 35, pp. 59916002, 2007.

[12] FAO, FAOSTAT Statistics Database, 2011, http://faostat.fao.org/.

[13] M. A. Baqui, "Present status and future potential of utilization of rice-by-products in Bangladesh," in Proceedings of the Joint International Conference on Agricultural Engineering and Technology, Bangladesh Society of Agricultural Engineering, vol. 1, pp. 284-288, 1997.

[14] M. S. U. Talukder and S. M. Shirazi, "Performance of different tillage implements and irrigation regimes on yield of wheat," in Proceedings of the Joint International Conference on Agricultural Engineering and Technology Exhibition, vol. 1, pp. 3137, Bangladesh Society of Agricultural Engineering, Dhaka, Bangladesh, 1997.

[15] Biswas and Khan, Project Report on Utilization and Estimation of Crop Biomass and Bio-Energy, Department of Farm Power and Machinery, Bangladesh Agricultural University, Mymensingh, Bangladesh, 2000.

[16] S. M. I. Hossain, M. A. Zaman, M. M. Huq, and M. Abdullah, "Potential of sugarcane as a renewable source of energy in Bangladesh," Journal of Agricultural Machinery \& Mechanics, vol. 1, no. 1, pp. 47-52, 1994.

[17] M. R. I. Mondal and M. A. Wahhab, Production Technology of Oilcrops, Oilseed Research Centre, Bangladesh Agricultural Research Institute, Gazipur, Bangladesh, 2001.

[18] M. A. Zaman, "Biomass and bioenergy potentials of selected agricultural crops," in Proceedings of the National Seminar on Renewable Energy: Biomass/Bio Energy, Dhaka, Bangladesh, March 2006.

[19] O. M. Ali, Production through relay cropping in transplant aman rice in medium low lands of Bangladesh [Ph.D. thesis], Department of Botany, Life and Earth Science Faculty, Rajshahi University, Rajshahi, Bangladesh, 2010.

[20] Schaffer \& Associates International, Rice Husk to Energy: A Preliminary Assessment for the Republic of Mali, Schaffer \& Associates International, Baton Rouge, La, USA, 2005. 
[21] G. Tchobanoglaus, H. Theisen, and R. Eliassen, Solid Wastes: Engineering Principles and Management Issues, McGraw-Hill, New York, NY, USA, 1977.

[22] Waste Concern, http://www.wasteconcern.org/.

[23] M. Alamgir and A. Ahsan, "Municipal solid waste and recovery potential: Bangladesh perspective," Iranian Journal of Environmental Health Science and Engineering, vol. 4, pp. 67-76, 2007.

[24] S. Cointreau, Environmental Management of Urban Solid Wastes in Developing Countries: A Project Guide, Urban Development Department, World Bank, Washington, DC, USA, 1982.

[25] A. D. Pasek, K. W. Gultom, and A. Suwono, "Feasibility of recovering energy from municipal solid waste to generate electricity," Journal of Engineering \& Technological Sciences, vol. 45, no. 3, pp. 241-256, 2013.

[26] J. A. Wess, L. D. Olsen, and M. H. Sweeney, Concise International Chemical Assessment Document 59. Asphalt (Bitumen), World Health Organization, Geneva, Switzerland, 2004, http://www.who.int/ipcs/publications/cicad/en/cicad59.pdf.

[27] N. Othman, N. E. A. Basri, N. M. Yunus, and L. M. Sidek, "Determination of physical and chemical characteristics of electronic plastic waste (Ep-Waste) resin using proximate and ultimate analysis method," in Proceedings of the International Conference on Construction and Building Technology, pp. 169180, 2008.

[28] Fehily Timoney \& Company (FTC), Waste Strategy for South East Region, Fehily Timoney and Company Core House, Cork, Ireland, 1999.

[29] IEA, Energy Technology Essentials-Biomass for Power Generation and CHP, IEA, Paris, France, 2007.

[30] A. Demirbas, "Producing bio-oil from olive cake by fast pyrolysis," Energy Sources A, vol. 30, pp. 38-44, 2008.

[31] T. Kapur, T. C. Kandpal, and H. P. Garg, "Electricity generation from rice husk in Indian rice mills: potential and financial viability," Biomass Bioenergy, vol. 10, pp. 393-403, 1996.

[32] H. Abe, A. Katayama, B. P. Sah, T. Toriu, S. Samy, and P. Pheach, "Potential for rural electrification based on biomass gasification in cambodia," Biomass Bioenergy, vol. 31, pp. 656-664, 2007.

[33] T. A. Milne, N. Abatzoglou, and R. J. Evans, "Biomass gasifier "tars": their nature, formation and conversion," Tech. Rep. NREL/TP-570-25357, NREL, 1998.

[34] P. Quaak and H. Knoef, Energy from Biomass: A Review of Combustion and Gasification Technologies, WB Technical Paper no. 422-Energy Series, 1999.

[35] TERI, "RETs II theme-thermal applications of biomass gasifier in SMiEs," Project Report 2005BE28, The Energy and Resources Institute, New Delhi, India, 2006.

[36] D. Dayton, A Review of the Literature on Catalytic Biomass Tar Destruction: Milestone Completion Report, NREL/TP, Golden, Colo, USA, 2002.

[37] C. Turare, Biomass Gasification Technology and Utilization, Artes Institute, University of Flensburg, Flensburg, Germany, 1997.

[38] K. Maniatis, "Progress in biomass gasification: an overview," in Progress in Thermochemical Biomass Conversion, A. Bridgwater, Ed., Blackwell Publishing, Oxford, UK, 2001.

[39] Environmental Protection Agency Combined Heat and Power Partnership (EPA-CHP), Biomass Conversion Technologies in Biomass Combined Heat and Power Catalog of Technologies, Environmental Protection Agency, Washington, DC, USA, 2007.
[40] V. V. N. Kishore, Ed., Renewable Energy, Engineering and Technology: A Knowledge Compendium, The Energy and Resources Institute, New Delhi, India, 2008.

[41] S. Dasappa, D. N. Subbukrishna, K. C. Suresh, P. J. Paul, and G. S. Prabhu, "Operational experience on a grid connected $100 \mathrm{kWe}$ biomass gasification power plant in Karnataka, India," Energy for Sustainable Development, vol. 15, no. 3, pp. 231-239, 2011.

[42] S. Ghosh, T. K. Das, and T. Jash, "Sustainability of decentralized woodfuel-based power plant: an experience in India," Energy, vol. 29, no. 1, pp. 155-166, 2004.

[43] B. C. Jain, "Commercialising biomass gasifiers: Indian experience," Energy for Sustainable Development, vol. 4, no. 3, pp. 7282, 2000.

[44] N. H. Ravindranath, H. I. Somashekar, S. Dasappa, and C. N. J. Reddy, "Sustainable biomass power for rural India: case study of biomass gasifier for village electrification," Current Science, vol. 87, no. 7, pp. 932-941, 2004.

[45] H. A. M. Knoef, Handbook Biomass Gasification, Biomass Technology Group, Enschede, The Netherlands, 2005.

[46] G. Sridhar, H. V. Sridhar, S. Dasappa, P. J. Paul, D. N. Subbukrishna, and N. K. S. Rajan, "Green electricity from biomass fuelled producer gas engine," in Proceedings of the 14th European Biomass Conference \& Exhibition Biomass for Energy, Industry and Climate Protection, pp. 1489-1492, Paris, France, 2005.

[47] A. M. Gokhale, A. K. Gupta, J. Kishwan et al., National Mission on Decentralized Biomass Energy for Villages and Industries, 2006.

[48] M. Ahiduzzaman, "Rice husk energy technologies in Bangladesh," Agricultural Engineering International: The CIGRE Journal, vol. 9, no. 1, 2007.

[49] Environmental Protection Agency Combined Heat and Power Partnership (EPA-CHP), Biomass Conversion Technologies in Biomass Combined Heat and Power Catalog of Technologies, Environmental Protection Agency, Washington, DC, USA, 2007.

[50] S. C. Bhattacharya and P. A. Salam, A Review of Selected Biomass Energy Technologies, Asian Regional Research Programme in Energy, Environment and Climate (ARRPEEC), Asian Institute of Technology (AIT), Bangkok, Thailand, 2006.

[51] R. I. Singh, "Combustion of biomass in an atmospheric Fbc: an experience and study," in Proceedings of the International Conference on Advances in Energy Research, Indian Institute of Technology Bombay, December 2007.

[52] R. P. Singh, V. V. Tyagi, T. Allen, M. H. Ibrahim, and R. Kothari, "An overview for exploring the possibilities of energy generation from municipal solid waste (MSW) in Indian scenario," Renewable and Sustainable Energy Reviews, vol. 15, no. 9, pp. 4797-4808, 2011. 


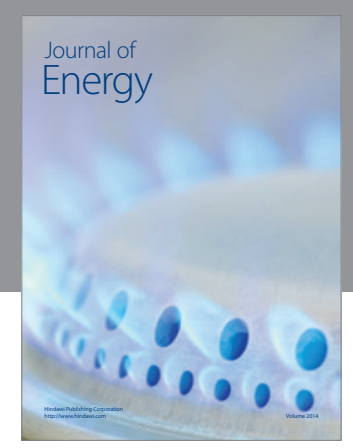

Journal of

Industrial Engineering
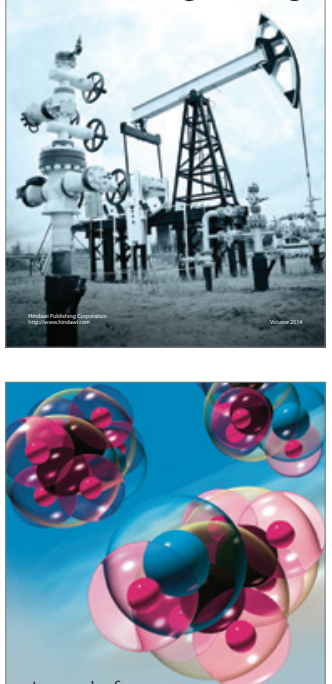

Fuels
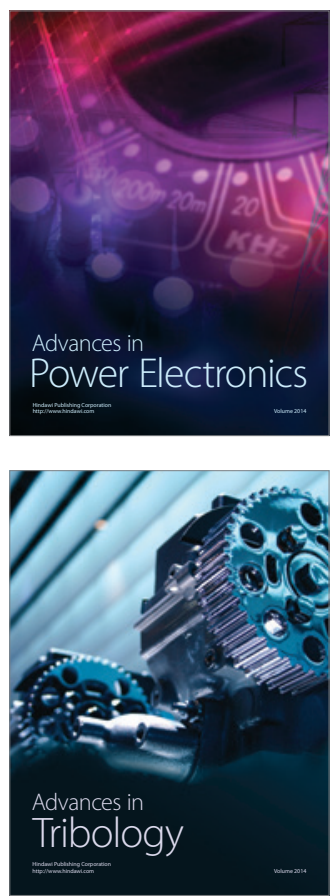

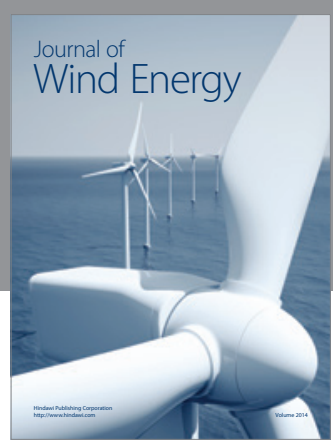

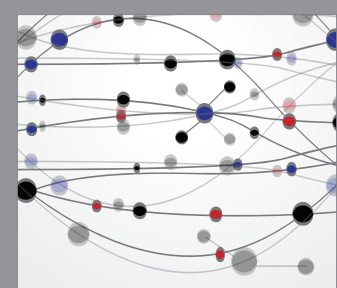

The Scientific World Journal

Submit your manuscripts at http://www.hindawi.com

Journal of

Structures
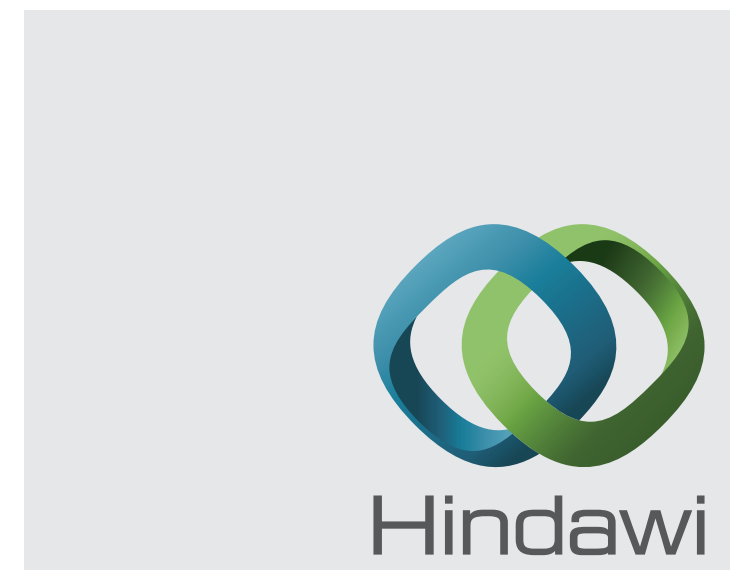

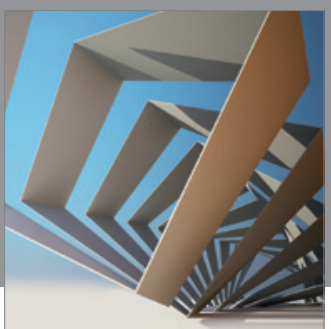

Rotating

Machinery
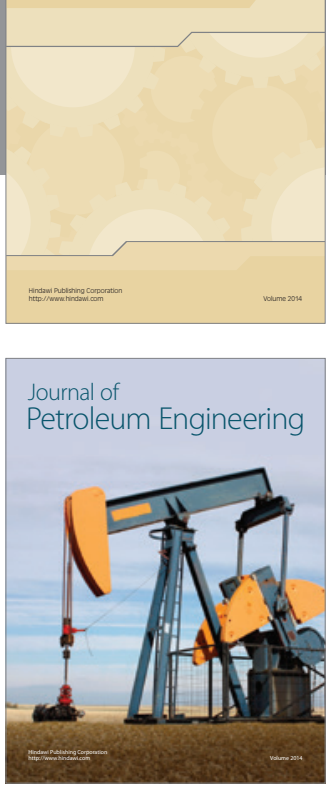

Journal of

Solar Energy
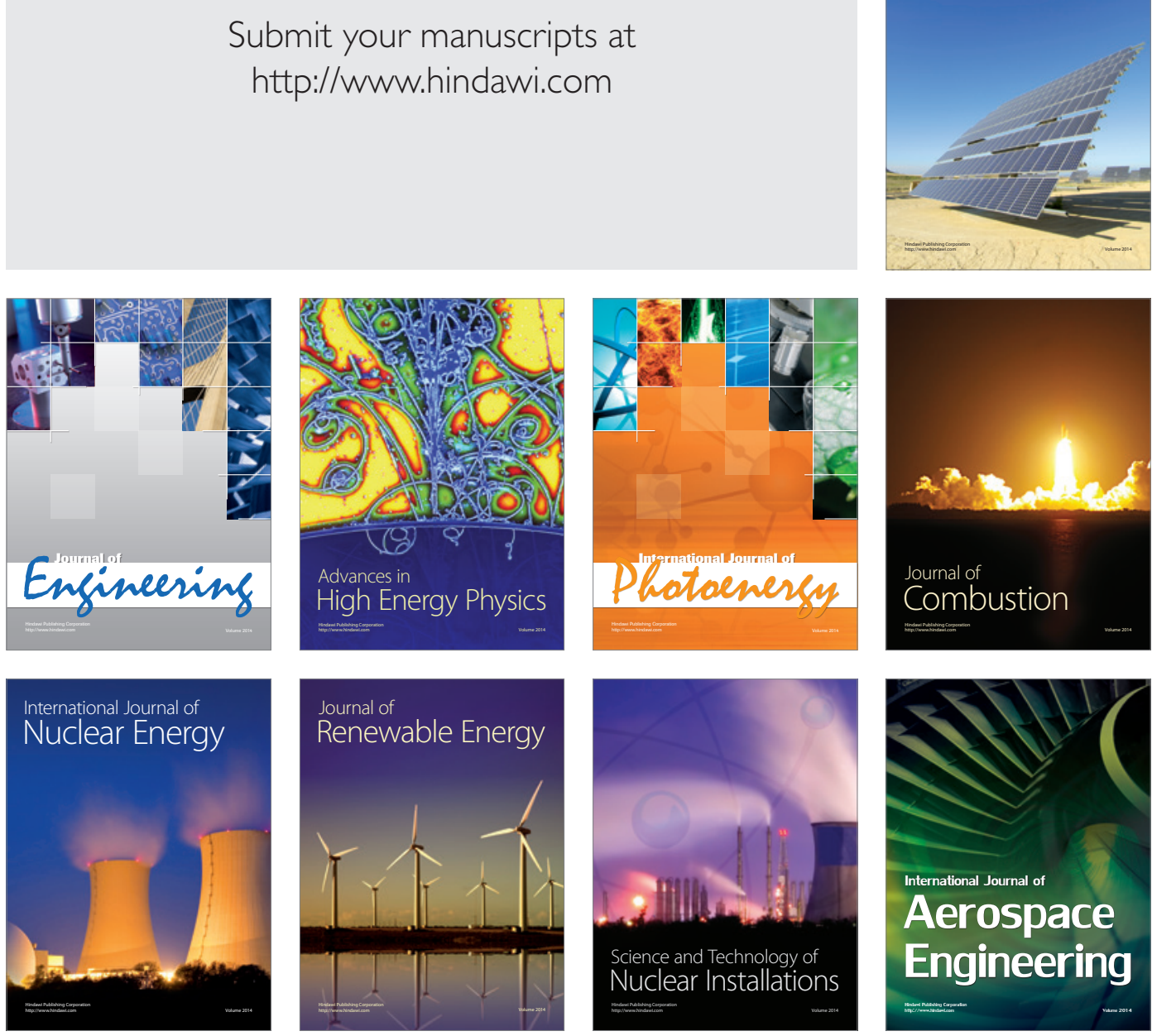